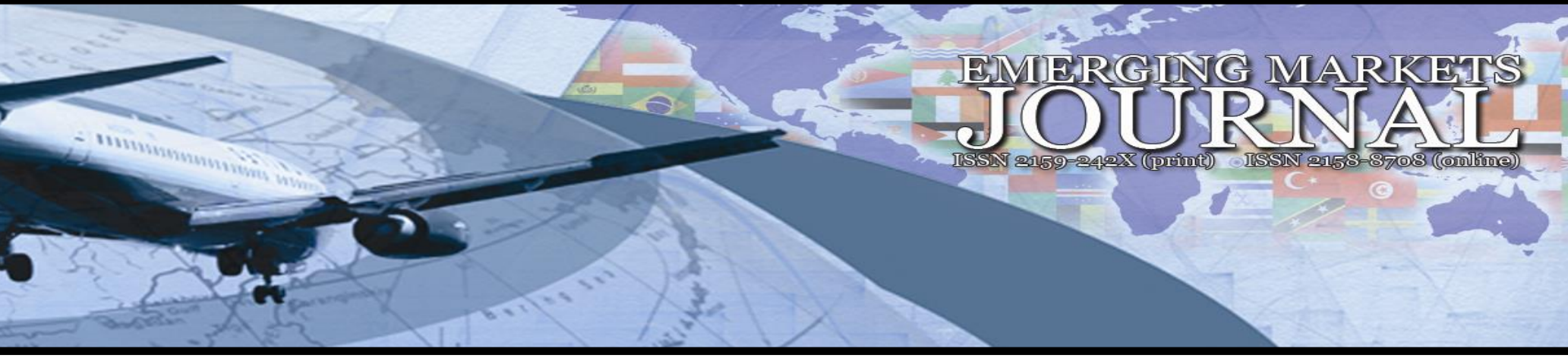

\title{
Organizational Culture and Intrapreneurship Growth in Nigeria: Evidence from Selected Manufacturing Firms
}

\section{Benneth Uchenna Eze}

Hallmark University, Nigeria | beneze7@gmail.com

\section{Adekunle Abdul}

Olabisi Onabanjo University, Nigeria | abduladekule3@gmail.com

\section{Emmanuel Kanayo Nwaba}

Olabisi Onabanjo University, Nigeria | nwabakanayo@gmail.com

\section{Azeez Adebayo}

Olabisi Onabanjo University, Nigeria | bayoazeez@gmail.com

Volume 8 No 1 (2018) ｜ ISSN 2158-8708 (online) | DOI 10.5195/emaj.2018.147 | http://emaj.pitt.edu |

\begin{abstract}
The study examines the effect of organizational culture (measured by organizational norms and organizational shared values) on intrapreneurship growth in manufacturing sector of the Nigerian economy. Survey research design was used through the administration of structured questionnaire to members of staff of Nestle Nigeria PLC and PZ Cussons Nigeria PLC. The population of the study consist 2325 and 3500 staff of Nestle Nigeria PLC and PZ Cussons Nigeria PLC respectively. Using the Raosoft sample size determination technique, a sample size of 359 was obtained. The findings revealed that, organizational culture positively and significantly affect intrapreneurship growth in manufacturing firms in Nigeria. The study further revealed that, organizational norms and organizational shared values significantly affect intrapreneurship growth in the manufacturing sector in Nigeria, with coefficient and probability values of $\left(\beta_{1}=0.982\right.$, $\mathrm{p}<0.05)$ and $\left(\beta_{2}=0.901, \mathrm{p}<0.05\right)$ respectively. The adjusted coefficient of determination (adj. $\mathrm{R}$ squared) revealed that, organizational culture elements account for $69.8 \%$ variation in intrapreneurship growth. Thus, the study concluded that organizational culture plays a significant role in promoting intrapreneurship growth. It is recommended that, manufacturing firms should enhance their organizational norms as well as their organizational shared values towards the growth of intrapreneurship within their firms.
\end{abstract}

Keywords: Intrapreneurship, Organizational Culture, Organizational Norms, Organizational Shared Values

(cc) BY

New articles in this journal are licensed under a Creative Commons Attribution 3.0 United States License.

\section{UILIS D-SulR}

This journal is published by the University Library System of the University of Pittsburgh as part of its D-Scribe Digital Publishing Program, and is cosponsored by the University of Pittsburgh Press. 


\section{Organizational Culture and Intrapreneurship Growth in Nigeria: Evidence from Selected Manufacturing Firms}

\author{
Benneth Uchenna Eze \\ Adekunle Abdul \\ Emmanuel Kanayo Nwaba \\ Azeez Adebayo
}

\section{Introduction}

Intrapreneurship has engendered a lot of research interest in the developed, emerging and developing economies. Intrapreneurship refers to entrepreneurs within an organization, who are considered as tools for achieving strategic organizational goals. According to Gursoy (2016), the growth of intrapreneurship activities in an organization tends to enhance organizational performance. McDowells (2017) opines that, intrapreneurship is both a cultural and behavioural pattern which can aid organizations to have competitive advantage in an ever changing business and economic environment. According to Bau and Wagner (2015), intrapreneurial behaviour of an organization is the process by which employees are empowered to implement, promote and discover new business opportunities and create economic values inside established firms. Organization culture is a system of shared conjecture, values and beliefs which governs how people behave in organizations (Alvesson, 2013; Odor, 2018).

Scholars, such as Blanka (2018), Odor (2018), McDowells (2017), Otsu (2016), Moriano, Molero, Topa and Levy (2014), Witzell (2014) and Webb (2013) studied the concepts of organizational culture and intrapreneurship growth in isolation. In their findings, they revealed that organizational culture is important to an organizational performance and that intrapreneurship is of great importance to how innovative an organization would be. However, most of these studies were carried out in the developed and emerging economies and most of the studies examined the concepts (intrapreneurship and organizational culture) separately.

In addressing that research gap, this study connects the two concepts that are traditionally investigated separately. Furthermore, considering the social, economic, political and cultural differences between Nigeria and the developed economies as well as the rarity of similar studies in Nigeria, this study seeks to examine the effect of organizational culture (measured by organizational norms and organizational shared values) on intrapreneurship growth in Nigeria.

\section{Literature Review}

Intrapreneurship is principally concerned with the traits of intrapreneurial individuals and the means of utilizing these individuals in the pursuit of corporate innovation. Dauber et al. (2012) opine that, individual champions are commonly involved in corporate innovation. These individuals are employees of organization leading the organizational innovative efforts. Blanka (2018) asserts that, new opportunity recognition stems from individuals rather than organizational processes. The individual dimension separates intrapreneurship from the concept of corporate entrepreneurship.

The term intrapreneur was conceptualized based on the work of Pinchot (1985). It refers to entrepreneurial employees. That is the entrepreneurial activities within organization. Pinchot (1985) introduced the concept of intrapreneur as a combination of two concepts: Intracorporate and entrepreneur. Pinchot also stated that, intrapreneurs turn ideas into realities inside an organisation. Baruah and Ward (2015) identified three main differences between intrapreneurs and entrepreneurs: Intrapreneurs are able to use the existing resources of the companies, they operate within organizations and they work within firms that already have their own policies and structures.

Corporate entrepreneurship refers to the entrepreneurial activities of corporate organizations. The concept of intrapreneurship is closely linked to corporate 
entrepreneurship, but they are not the same (Moriano et al., 2014). Rigtering and Weitzel (2013) assert that, one major differentiating feature between corporate entrepreneurship and intrapreneurship is that, corporate entrepreneurship can be seen as an innovative process initiated from the top-down within an organization, whereas intrapreneurship can be seen as a bottom-up approach related to the intrapreneurial behaviour of employees.

Kuz (2010) introduces a prototype of an intrapreneur, providing a set of characteristics for individual intrapreneurs, including advanced emotional intelligence, extensive network building capabilities, as well as ability to work in multiple organizational domains from product development to strategy building, business development as well as market research. According to this view, intrapreneurs possess a natural tendency of creating more intrapreneurship, provided that they are granted power in the organization. In case of leader intrapreneurs, they intuitively direct themselves to hire other intrapreneurial individuals or help create more intrapreneurs from the existing organizational members through inclusion in their work and their network approach (Blanka, 2018).

Kuz (2010) has suggested an enabler model of intrapreneurship, consisting of a set of behaviours that can be utilized for the growth of intrapreneurship within an organization. The model starts with the presupposition that certain individuals exist with intrapreneurial characteristics, which should be utilized as change agents for driving the development and growth of intrapreneurship. These set of behaviours consists of seven constructs; value proposition creation, idea champion roles, enabling innovation networks, exploiting technology intersections, culture change agency, enabling workforce creativity, and intrapreneur resource growth (Kuz, 2010).

Intrapreneurship has also been examined as a team level phenomenon. Teams represent a central unit for creating new ventures, as they bring together a pool of talent with versatile skills and knowledge, thus creating an interface for new initiatives to emerge.
Teamwork is frequently utilized as a tool in improving organization-wide cooperation, facilitating idea sharing and thus creating a favourable environment for intrapreneurship to thrive (Eesley and Longenecker, 2006; Blanka, 2018).

\subsection{Organization Culture}

Organization culture is a system of shared assumptions, values and beliefs which governs how people behave in an organization. These shared values have a strong influence on the people in the organization and dictate how they act, dress and perform their duties (Odor, 2018). Given the relative importance of organizational culture in innovative organizations, it is hardly surprising that intentional and planned culture change efforts represent a widespread phenomenon in corporate environments. New management tools and trends emerge on a regular basis to guide organizational growth, and they are relentlessly applied by managers to render their organizations more innovative, effective and competitive. Organizational culture is widely recognized as an important component in all organizational change processes and innovativeness (Alvesson and Sveningsson, 2008; Odor, 2018).

Yildiz (2014) posits that organizational culture is strategically important to intrapreneurship, as it affects organization process which enhances firm survival and performance. Paunovic and Dima (2014) examined the effect of organizational culture on corporate entrepreneurship with a view of establishing the effect of organizational culture on intrapreneurship. They suggested that keeping and increasing competitive advantages in a relatively longer period of time has become very difficult and challenging for businesses and that for organizations to survive in a very turbulent business environment, large organizations are under the pressure of constant changes while struggling to overcome what has been done in the near past. The business strategies that are based on passive adaptation to changes increasingly give way to the innovation-based proactive strategies, which means the implementation of different forms of intrapreneurship. 
McDowells (2017) viewed intrapreneurship as a cultural form of innovation and sustainable competitive advantage and posit that, intrapreneurial activity within the organization varies within the contexts of employee perception and motivation.

\subsection{Theoretical Review}

Several theories have attributed entrepreneurial characteristics, such as entrepreneurial passion to personality, considering them as fixed individual traits (Cardon, 2009). Characteristics such as ability to take risk, desire for autonomy and achievement, goal orientation and intrinsic motivation and control are often viewed as individual characteristics favorable for the growth of intrapreneurial behaviour (Dauber et al, 2012; Hashimoto and Nassif, 2014). This study concentrates on the theory of planned behaviour and organizational perspective theory.

Theory of planned behaviour is rooted in rational models, where decisions are based on the probabilities of different outcomes. The theory postulates that, behaviour is a product of three elements: Beliefs about the attributes of an object, the degree of intensity of these beliefs, the evaluation of the attributes (good or bad) as well as the confidence of an individual (Antoncic, 2003). This theory provides a framework through which context-bound individual behaviour can be analyzed through a set of psychological human cognitions (Antoncic, 2003).

Organization perspective theory reverberates with the non-rational, affective elements of individuals, and provides a sense of collective membership and belonging that is a general human characteristic (Antoncic, 2003). Organizational theory is based on its three perspectives, which are the modern, symbolicinterpretive and the post-modern. The perspectives each have different approaches when it comes to the management of an organization. Modernists are objectivists who focus on reality of knowledge, which is built based upon the conceptualization and the theorization. An example would be that, a company earns profits based on the CEO's ability to make right decisions while investing the money of an organization. The results of the actions can be measured in profit and loss, and can be directly measured.

\section{Methodology}

The study employs survey research design. This design enables the researcher to get relevant information needed for the study. Since the study covered a large number of respondents, the survey design is the most suitable. Related studies (Brigic and Umihanic, 2015; Findik and Altindag, 2017) also utilized survey research design.

The population of the study consist 2325 and 3500 staff of Nestle Nigeria PLC and PZ Cussons Nigeria PLC respectively. Using the Raosoft sample estimator software which is based on normal distribution at error margin of 5 and $95 \%$ significant level, the aggregate sample for this study is 359 staff. The study employed a structured questionnaire as the instrument of data collection. A 9 point Likert scale, ranging from 1 (minimum) to 9 (maximum) was used to obtain data from the target respondents.

Content Validity Index (CVI) is employed to test the validity of the research instrument, through the independent assessment of 3 academic staff of Lagos State University. The assessors rated the instrument on two scale (relevant and not relevant) using the CVI formula $\mathrm{n} / \mathrm{N}$

Where;

$\mathrm{n}$ is number of questionnaire items ticked as relevant $\mathrm{N}$ is the total number of the questionnaire items

A CVI value of 0.86 was obtained, which indicates that the research instrument is valid. A pilot study was conducted to ascertain the reliability of the research instrument. The instrument was administered to 30 members of staff of Cadbury Nigeria PLC twice within an interval of two weeks. The outcome of the first pilot study was correlated with that of the second and a Cronbach alpha of 0.811 was obtained, which indicated that the instrument (questionnaire) is reliable. 
Model Specification

INTRGRO $=\beta_{0}+\beta_{1}(\text { ORGNORMS })_{\mathrm{i}} \quad+\beta_{2}(\text { ORSHVA })_{\mathrm{i}}$

$+\mu_{\mathrm{i}} \ldots \ldots \ldots \ldots \ldots \ldots$ (1)

Where;

INTRGO is Intrapreneurship Growth

ORGNORMS is Organizational Norms

ORSHVA is Organization Shared Value

$\beta_{0}$ is the constant term

$\beta_{1}, \beta_{2}$, are the coefficient estimators

Where $\mu$ is error term

\section{Statement of Hypotheses}

In line with the objectives of this study, the following research hypotheses were tested:

Ho1: Organizational norms do significantly affect intrapreneurial growth in manufacturing firms in Nigeria.

Ho2: Organizational shared values do significantly affect intrapreneurial growth in manufacturing firms in Nigeria.

Ho3: Organizational culture elements do significantly affect intrapreneurial growth in manufacturing firms in Nigeria.

Apriori Expectation

All the measures of organizational culture are expected to exhibit positive relationship with intrapreneurship growth; hence there will be a positive relationship between organizational culture elements and intrapreneurship growth in the above model. .i.e. $\beta 1, \beta 2$, $>0$

Categorical regression was employed to test the model, with the aid of STATA version 14 .

\section{Findings and Discussion}

The results on table 1 below revealed that, both organizational norms and organizational shared values have a positive and significant effect on intrepreneurship growth. The F-statistics $(49.12 * 0.000)$ indicates that, organizational culture elements have a positive and significant effect on intrapreneurship growth. The adjusted $\mathrm{R}$ square revealed that, organizational culture elements account for $69.8 \%$ variation in intrapreneurship growth. Thus, the hypotheses of Ho1, Ho2 and Ho3 are accepted.

Table 1: Summary of categorical regression result

(Dependent Variable - Intrapreneurship Growth)

\begin{tabular}{|l|l|c|l|}
\hline \multicolumn{1}{|c|}{ Variable(s) } & Coefficient & Fc & P-Value \\
\hline $\begin{array}{l}\text { Organizational } \\
\text { Norms }\end{array}$ & $0.982^{*}$ & 4.601 & 0.000 \\
\hline $\begin{array}{l}\text { Organizational } \\
\text { Shared Value }\end{array}$ & $0.901^{*}$ & 4.052 & 0.000 \\
\hline $\begin{array}{l}\text { R square } \\
=0.716\end{array}$ & Adjusted R & & F Stat \\
NB: & square $=$ & & $=49.12(0.000)$ \\
$*$ Significant at & & & \\
$5 \%$ level & & & \\
\hline
\end{tabular}

\section{Conclusion and Recommendations}

The study examined the effect of organizational culture (measured by organizational norms and organizational shared values) on intrapreneurship growth in two selected manufacturing firms, using survey research design. The findings revealed that, organizational culture positively and significantly affect intrapreneurship growth in manufacturing firms in Nigeria.

Also, the study further revealed that organizational norms and organizational shared values significantly affect intrapreneurship growth in the manufacturing sector in Nigeria, with coefficient and probability values of $0.982(0.000)$ and $0.901(0.000)$ respectively. This further indicates that, organizational norm has the highest effect on intrapreneurship growth. The adjusted coefficient of determination (adj. R squared) revealed that, organizational culture elements account for $69.8 \%$ variation in intrapreneurship growth.

The study indicated that, organizational norms and organizational shared values are the critical elements of organizational culture driving intrapreneurship growth. Thus, the study concluded that, organizational culture plays a significant role in promoting intrapreneurship growth. It is recommended that, manufacturing firms should enhance their organizational norms as well as 
their organizational shared values towards the growth of intrapreneurship within their firms.

\section{References}

Alvesson, M. (2013). Understanding organizational culture. London, UK: Sage.

Alvesson, M. and Sveningsson, S. (2008). Changing organizational culture. New York: Routledge.

Antoncic, B. (2003). Risk taking in intrapreneurship: Translating the individual level risk aversion into the organizational risk taking. Journal of Enterprising Culture, 11(1), 1-23.

Anu, L. (2007). Fostering intrapreneurial :The new competitive edge, Conference on Global Competition \& Competiveness of Indian Corporate.

Baruah, B. and Ward, A. (2015). Metamorphosis of intrapreneurship as an effective organizational strategy. International Entrepreneurship Management Journal, 11, 811-822. https://doi.org/10.1007/s11365-014-0318-3

Bau, F. and Wagner, K. (2015). Measuring corporate entrepreneurship culture. International Journal of Entrepreneurship and Small Business 25(2), 231-244.

Blanka, C. (2018). An individual-level perspective on intrapreneurship: A review and ways forward. Review of Managerial Science, 12(1), 1-43.

Brigić, M. and Umihanić, B. (2016). Intrapreneurship impact on growth of production companies in Bosnia and Herzegovina. Econviews Journals, 3(1), 393-408.

Cardon, M. (2009). The nature and experience of entrepreneurial passion. Academy of Management Review 34(3), 511-532.

Cowles, B. (2015). Question mark culture: how culture affects entrepreneurship at Amazon. An unpublished doctoral thesis. Department of Management, Entrepreneurship, and Leadership, Texas Christian University.

Dauber, D., Fink, G., and Yolles, M. (2012). A configuration model of organizational culture. Sage Open, 2(1), 1-16.

Eesley, D. T. and Longenecker, C. O. (2006). Gateways to intrapreneurship. Industrial Management 48(1), 18-23.

Fındık, G. and Altındağ, E. (2017). The effect of entrepreneurship and culture on the employee commitment in Turkey. American Journal of Economics and Business Administration. 9 (1), 13-26.
Gapp, R., and Fisher, R. (2007). Developing an intrapreneur-led three-phase model of innovation. International Journal of Entrepreneurial Behavior \& Research, 13(6), 330-348.

Gursoy, A. (2016). Effect of innovative culture on intrapreneurship. International Journal of Business and Social Science. 7(1).

Hashimoto, M. and Nassif, V. (2014). Entrepreneurs self-perception of planning skills: Evidences from Brazilian entrepreneurs. RevistalberoAmericana de Estratégia - RIAE, 3(4), 1-15.

Janczak, S. and Boiteux, S. (2007). Understanding intrapreneurship: A process model for the logic of action used by intrapreneurs. Journal of Business and Entrepreneurship 19(1).

Kuz, D. S. (2010). Exploration of intrapreneurship and innovation in advanced technology organizations in the Western United States. Unpublished Doctoral Dissertation, University of Phoenix.

McDowells, C.T. (2017). A comprehensive study of intrapreneurship as a cultural form of innovation and sustainable competitive advantage. An unpublished masters dissertation, Bisk College of Business, Florida Institute of Technology.

Moriano JA, Molero F, Topa G. and Lévy-Mangin, J.P. (2014). The infuence of transformational leadership and organizational identifcation on intrapreneurship. International Entrepreneurship Management Journal, 10, 103-119. https://doi. org/10.1007/s11365-0110196-x

Odor, H.O. (2018). Organizational culture and dynamics. Global Journal of Management and Business Research, 18(1).

Otsu, A. (2016). An exploratory story of intrapreneurship development: The role of organizational factors. International Journal for Research in Business, Management and Accounting, 3(2).

Paunovic, S. and Dima, C. (2014). Organizational culture and corporate entrepreneurship. Annals of the University of Petroşani, Economics, 14(1), 269-276.

Pinchot, G. (1985). Intrapreneuring: Why you don't have to leave the corporation to become an entrepreneur. Harper \& Row, New York.

Rigtering, J.P.C. and Weitzel, U. (2013). Work context and employee behaviour as antecedents for intrapreneurship. International Entrepreneurship Management Journal, 9, 337360. https://doi.org/10.1007/s11365-013-02583. 
Webb, T. (2013). Building an intrapreneurial culture: A sine-quanon for organizations' today. Global Journal of Management and Business Studies, 3(8), 849-854.

Witzell, U. (2014). Metamorphosis of intrapreneurship as an effective organizational strategy. New York: Springer Science+Business Media. DOI 10.1007/s11365-014-0318-3. 